\title{
Development of Learning Devices Based on Guided Discovery to Improve Students' Mathematical Reasoning Ability and Self-Esteem
}

\author{
Ana Febrianti Siregar ${ }^{*} \quad$ Izwita Dewi ${ }^{2} \quad$ Hasratuddin $^{2}$ \\ 1.Mathematics Education Study Program Postgraduate, State University of Medan, Jl. William Iskandar Psr.V \\ Medan Estate, PO box 20221, North Sumatera, Indonesia \\ 2.Lecturer State University of Medan, Jl. William Iskandar Psr.V Medan Estate, PO box 20221, North Sumatera, \\ Indonesia
}

\begin{abstract}
This study generally aims to produce learning devices based on the guided discovery that can improve students' mathematical reasoning ability and self-esteem. Specifically, this study aims to: 1) analyze the validity of learning devices developed based on guided discovery, 2) analyze the practicality of learning devices developed based on guided discovery, 3 ) analyze the effectiveness of learning devices developed based on guided discovery, 4) analyze the increase in students' mathematical reasoning ability who learn with learning devices developed based on guided discovery, and 5) analyze the increase in students' self-esteem who learn with learning devices developed based on guided discovery. The type of research is development research using a 4-D Model. The results showed that: (1) learning devices developed based on guided discovery met valid criteria based on expert judgment; (2) learning devices developed based on guided discovery met practical criteria, in terms of a) expert judgment and b) the results of observations of the learning device implementation; (3) learning devices developed based on guided discovery met effective criteria, in terms of a) the student learning completeness classically has been achieved in the trial II by $91,43 \%$ and the disseminated stage by $94,29 \%$, b) the achievement of learning purpose has been achieved for each item, c) the learning time used does not exceed or equals the normal learning time, and d) the student responses positive to learning devices; (4) the students' mathematical reasoning ability increased with an average of N-Gain by 0,53 in the medium category; and (5) the students' self-esteem increased with an average NGain by 0,49 in the medium category.
\end{abstract}

Keywords: development of learning devices, 4-D model, guided discovery-based learning, mathematical reasoning ability, self-esteem

DOI: $10.7176 / \mathrm{JEP} / 11-3-12$

Publication date: January $31^{\text {st }} 2020$

\section{Introduction}

Education is one of the factors of change because humans can make various changes in every area of life through the education they have enjoyed. Humans as a creature that is endowed with reason to think should use it well, one of which is with reasoning. Reasoning aspect is the ability which has been had by the learners as a standard which enables a person can master the concept generally and specifically in depth (Dewi \& Harahap, 2016: 68). With the ability to reason someone can make various changes.

Apart from being a factor of change, education is also closely related to the progress of science and technology. One of the lessons that support the advancement of science and technology in mathematics. As stated by Achera, Belecina \& Garvida (2015: 331), "mathematics has a great influence in all areas of studies". Mathematics is one of the disciplines that support other sciences, such as natural and social sciences. Because of its important role, mathematics is taught in every education unit and every class with more teaching hours when compared to other subjects (Sunismi, 2015: 334). With its huge role in the world of education and the progress of science and technology in the future, mathematics learning must take place effectively. The implementation of effective learning is inseparable from the role of the teacher, especially in designing and preparing learning in the classroom. Teachers as educators are expected to have the ability to design and manage teaching and learning activities that can attract students to actively participate in it with the aim of improving students' mathematical reasoning abilities.

Safitri \& Arnawa (2019: 131) suggested that "Mathematical reasoning skill is an individual ability to think logically based on the existed evidence". The importance of mathematical reasoning ability is no doubt. Rafiqoh, Syahputra \& Surya (2015: 110) argues that reasoning is important for every student, especially students who study mathematics related to the ability to form logical thinking, mastering concepts correctly and correctly, and drawing conclusions that are authentic where all of these factors are steps and strategies to solve mathematical problems.

The success of students in reasoning is influenced by many factors, one of which is self-esteem. With selfesteem, students will not hesitate to reason even students' confidence in their abilities will emerge. Prihadi \& Chua (2012: 2) say that students who have positive self-esteem are people who feel confident about their self-worth ('I am good and deserve to get the attention and respect of my friends and teachers') and a sense of competence - 
themselves ('I am able to face the challenges I face in the present and future that I face in life'). So with self-esteem, students will feel able to do something and deserve to be appreciated.

However, based on the results of observations that have been made, it is found that the learning devices used in the learning process, whether learning implementation plans, teacher books, student books, and student worksheets are inadequate and do not facilitate teachers and students to carry out learning. Of course, this is an obstacle from the teacher's side which will have an impact on student success in learning mathematics. In learning, students will encounter other obstacles such as often feeling that learning mathematics is very difficult and boring and assumes that learning mathematics is only about calculation problems and is not something important to be applied in daily life. Such assumptions are based on the lack of student knowledge about the application of mathematics and the lack of student understanding of the concepts of the material taught by the teacher (Siregar \& Jaya, 2016: 134). So this makes students tend to be passive in learning in class.

In order to be able to change the situation and conditions above, a learning model is needed that can increase the activeness of students to participate in the teaching and learning process, so students are expected to not only depend on the teacher as a source of learning but bring out independence to express ideas, creative ideas and able to overcome challenges skillfully in accordance with students' high reasoning abilities and self-esteem. In addition, teachers need to make sure that mathematics learning can be followed by students with good interest and activeness by making an appropriate learning device and in accordance with the material being taught and the objectives to be achieved. Learning that is felt to be appropriate and has never been developed by teachers until now is guided discovery-based learning. For this reason, the model chosen to be applied in the development of learning devices in this study is guided discovery-based learning.

With a guided discovery-based learning device, students can learn to find concepts or principles (theorems, formulas, characteristics) in materials that they learn themselves (Sunismi, 2015: 335). Sifanu (2018: 78) suggests that "Constructivists like Bruner emphasize that discovery learning enhances meaningful learning because a learner is able to relate new information to the information on the cognitive structure".

Based on this fact, it is necessary to develop a learning device. The development of a product in the form of a learning device can be said to be of quality if the device meets valid, practical, and effective criteria. For this reason, in this study, the learning devices that will be developed are the learning implementation plans (RPP), teacher books (BG), student books (BS), and student activity sheets (LKS). Based on this description, it is expected that the development of guided discovery-based learning devices can improve students' mathematical reasoning abilities and self-esteem.

\section{Research Methods}

This research is a research development that refers to the modification of the Thiagarajan model. This model consists of 4 stages of development, namely define, design, develop, and disseminate. The subjects in this study were eighth-grade students of SMP Negeri 24 Medan. While the object in this study is a guided discovery-based learning device on the materials of Straight Line Equations which includes Learning Implementation Plan (RPP), Teacher's Book (BG), Student's Book (BS), and Student Activity Sheet (LKS), and test instruments consisting of the Mathematical Reasoning Ability Test (TKPM) and self-esteem questionnaire. Instruments and data collection techniques were compiled to measure the validity, practicality, and effectiveness of the guided discovery-based learning device developed. The instruments used in this study were in the form of validation sheets, tests, questionnaires, and observation sheets.

The validity of the learning device is obtained based on the data of the validity assessment of learning devices oriented to the discovery-based learning guided by several competent experts in the field of mathematics learning device development, namely three UNIMED lecturers, and practitioners, namely two junior high school mathematics teachers determined the average value of indicators and grades aspects for each expert and practitioner. Data analysis of the learning device validation results is done by looking at the average of each category and the average of each aspect in the validation sheet until the average total number of validators are obtained against each learning device. Based on the Va value or the total average value obtained from a device, the category of validity is specified and the device is referred to in the determination of the validity intervals of the learning devices developed based on the guided discovery in the following Table 1:

Table 1. Validity Level Criteria

\begin{tabular}{ll}
\hline Index Total Average Value & Category \\
\hline $1 \leq V a<2$ & Invalid \\
\hline $2 \leq V a<3$ & Less Valid \\
\hline $3 \leq V a<4$ & Fairly Valid \\
\hline $4 \leq V a<5$ & Valid \\
\hline$V a=5$ & Very Valid \\
\hline \multicolumn{2}{c}{ (Modified from Tanjung \& Nababan, 2018:64) }
\end{tabular}

(Modified from Tanjung \& Nababan, 2018: 64)

Furthermore, the test instrument in the form of a mathematical reasoning ability test and a student's self- 
esteem questionnaire was tested on other students who were not sampled who had the same abilities as the students that will be researched, then the results of the instrument trial were analyzed using the validity and reliability test to find out to what extent valid and feasible test instruments. The construct validity can be measured using the product-moment correlation technique formula (Arnita, 2013: 87), as follows:

$$
r_{x y}=\frac{N\left(\sum X Y\right)-\left(\sum X\right)\left(\sum Y\right)}{\sqrt{\left\{N \sum X^{2}-\left(\sum X\right)^{2}\right\}\left\{N \sum Y^{2}-\left(\sum Y\right)^{2}\right\}}}
$$

Where,

$r_{x y}:$ The correlation coefficient of product-moment

$\mathrm{X}:$ Score of each question/item

Y : Total Score

$\mathrm{N}$ : Number of respondents

In search of the reliability of instruments whose scores are not 1 and 0 such as a poll or a form test, Arikunto (2013: 239) suggests the following Alpha formula:

$$
r_{11}=\left(\frac{k}{(k-1)}\right)\left(1-\frac{\sum \delta_{b}^{2}}{\delta_{t}^{2}}\right)
$$

Description: $r_{11} \quad$ : Reliability of the instrument

$k \quad$ : A number of question points or many problems

$\sum \delta_{b}^{2}$ : number of grain variances

$\delta_{i}^{2} \quad$ : Total Variance

Practicality analysis of learning devices developed based on guided discovery can be seen from 2 (two) aspects, namely: 1) expert assessment of learning devices developed based on guided discoveries which state that these devices can be used with little revision or without revisions and 2) the results of observations of the implementation of learning devices developed based on guided discoveries are in the minimum Good category. The practicality of learning devices is observed based on validator assessments. The five criteria for the general assessment of learning devices with value codes (Adibah, 2013: 11) are as follows:

Table 2. Expert Assessment Criteria

\begin{tabular}{ll}
\hline Code Value & Description \\
\hline A & Can be used without revision \\
\hline B & Can be used with a slight revision \\
\hline C & Can be used with many revisions \\
\hline D & Cannot be used \\
\hline
\end{tabular}

Further data from the observation sheet is analyzed by calculating the percentage of observation score using the formula (Mujahidah \& Suhendar, 2018: 61):

$$
P=\frac{\text { number of score earned }}{\text { maximum score }} \times 100 \%
$$

Remarks $\mathrm{P}=$ Percentage of observation score

After that, this learning device's implementation value is referred to at the time-determination interval of guided discovery-based learning devices that are categorized in the following Table 3:

Table 3. Implementation Level Criteria

\begin{tabular}{cl}
\hline Implementation Percentage Index & Category \\
\hline$P \geq 90$ & Very Good \\
\hline $80 \leq P<90$ & Good \\
\hline $70 \leq P<80$ & Enough \\
\hline $60 \leq P<70$ & Less \\
\hline$P<60$ & Very Less \\
\hline
\end{tabular}

(Modified from Sudjana (2005) (in Purnamasari \& Lestari, 2017: 25))

Then the learning devices developed in this study are said to be effective if they meet the following effectiveness indicators: 1) completeness of student learning in a classical manner, i.e. a minimum of $85 \%$ students score 75 ; 2) achievement of learning objectives, namely at least $75 \%$ learning objectives for each item of mathematical reasoning ability test items achieved; 3) achieving ideal time, is at least the same learning time as regular learning; and 4) student responses, i.e. at least $80 \%$ of students respond in a positive category to the learning component based on guided discoveries that are developed.

Meanwhile, in evaluating self-esteem one can use RSES with 10 items and a four-point response scale $(1=$ strongly agree; 2 = agree; 3 = disagree; and $4=$ strongly disagree). All item scores are added up and divided by 
the number of valid responses. Greater total scores indicate higher self-esteem (Switaj et al., 2017: 2473). Data obtained based on students' self-esteem questionnaires were analyzed to classify the results of self-esteem questionnaires which can be done using descriptive statistical formulas as follows:

- $\quad$ Highest score $=108$

- $\quad$ Lowest score $=27$

- $\quad$ Number of classes $=3$ range $=$ highest score

- $\quad$ range $=$ highest score - lowest score $=108-27=81$

- $\quad$ Interval $=$ range $/($ number of class $)=81 / 3=27$

After that, the overall level of students' self-esteem is obtained by descriptive analysis of the percentage of self-esteem based on the following formula (Julia, 2017: 3):

$$
S E=\frac{\text { actual score }}{\text { ideal score }} \times 100 \%
$$

Note: $\mathrm{SE}=$ percentage

Ideal score $=$ maximum score per item $\times$ the number of items $\times$ the number of respondents

Table 4. Descriptive Data Categories of Self-Esteem

\begin{tabular}{lll}
\hline Score Interval & Category & SE $(\%)$ \\
\hline $81 \leq \mathrm{STSE} \leq 108$ & High & $75 \leq \mathrm{SE} \leq 100$ \\
\hline $54 \leq \mathrm{STSE}<81$ & Medium & $50 \leq \mathrm{SE}<75$ \\
\hline $27 \leq \mathrm{STSE}<54$ & Low & $25 \leq \mathrm{SE}<50$ \\
\hline
\end{tabular}

Note: STSE $=$ total score of self-esteem

The amount of improvement in students' mathematical reasoning abilities and self-esteem can be calculated with the normalized N-Gain formula developed by Hake (in Barus, 2018: 17) as follows:

$$
\text { gain }=\frac{\text { Post }- \text { test Score }- \text { Pretest Score }}{\text { Maximum Ideal Score }- \text { Pretest Score }}
$$

With the following crites

Table 5. N-Gain Criteria

\begin{tabular}{ll}
\hline Improvement index & Category \\
\hline gain $\leq 0,3$ & Low \\
\hline $0,3<$ gain $\leq 0,7$ & Medium \\
\hline gain $>0,7$ & High \\
\hline
\end{tabular}

(Modified from Simanungkalit, 2016: 47)

\section{Research Result}

The development stage of learning devices uses a 4-D model consisting of 4 stages, namely the define, design, develop, and disseminate. The results of each of these stages are described as follows:

\subsection{Define}

Based on the results of observations made at SMP Negeri 24 that the curriculum used is the 2013 curriculum. Then an analysis of the learning devices at SMP Negeri 24 Medan shows that teachers do not have good learning devices, developing mathematical learning devices that are appropriate to the situations and conditions of students have never been done, and the teacher has not applied learning models that are relevant to the characteristics and objectives of mathematics learning just as the teacher has never applied guided discovery learning.

The Learning Implementation Plan (RPP) available does not describe the learning activities to be carried out by the teacher and students, other than that the question exercises are not adjusted to the indicators and learning objectives contained in the RPP. The textbook used does not contain mathematical reasoning questions or contextual questions. The unavailability of worksheets that are relevant to learning implementation plans and textbooks because the worksheets that are used tend to be ready-made worksheets that are widely traded, the contents of which are more directed to routine questions rather than student activities in finding knowledge. As in the matter of straight-line equations, students are not given the opportunity to discover the concept of straight-line equations themselves but instead are directly given concepts in finished form accompanied by formulas and examples of problems that are equipped with how to solve them. So this results in learning devices not in accordance with the objectives to be achieved. In addition, teacher-centered learning so that students do not have the opportunity to find knowledge or concepts from the material being studied. This is thought to be the cause of students' mathematical reasoning abilities and self-esteem is low.

\subsection{Design}

At this stage, the initial draft (Draft I) was prepared to design learning devices based on guided discoveries on the 
materials of Straight Line Equations so that a prototype (sample learning device) is obtained. The resulting learning devices are the Learning Implementation Plan (RPP), Teacher's Book (BG), Student's Book (BS), and Student Activity Sheet (LKS). The research instrument is a test of mathematical reasoning ability and student self-esteem questionnaire.

\subsection{Develop}

The first stage in the development stage is to validate the Draft I to the experts and then do a field trial. The validation of the experts focused on the format, language, illustrations, and content on the learning devices and research instruments developed. The results of expert validation in the form of validation values, corrections, criticisms, and suggestions are used as a basis for revising and refining the learning devices and research instruments developed. The revised learning devices and research instruments are learning devices and research instruments that have met the valid criteria and hereinafter referred to as Draft II.

3.3.1 Validation Results of Learning Devices and Research Instruments

Based on the results of expert validation, it is found that all learning devices developed to meet the validity criteria with an average total validity of RPP by 4,51 in the valid category, a teacher's book by 4,58 in the valid category, a student book by 4,60 in the valid category, and LKS by 4,49 in the valid category. While the research instruments validated by experts are test items (pretest and post-test) mathematical reasoning abilities are in the valid category and are quite valid and self-esteem questionnaire statements are in the valid category. Likewise, the results of the validity test of research instrument items in the form of tests (pretest and post-test) mathematical reasoning abilities and self-esteem questionnaires, respectively, are in the valid and reliable categories. Instrument reliability is used to determine the determination of test results. After calculating the reliability of the pretest mathematical reasoning ability by 0,724 (high category), the post-test mathematical reasoning ability by 0,732 (high category), and the self-esteem questionnaire by 0,944 (very high category).

\subsubsection{Field Trial Results}

\section{Trial I}

After the guided discovery-based learning device developed has met the validity criteria according to experts and the results of limited trials. Then the next learning device in the form of Draft II was tested in the field of research, namely students of class VIII-E SMP Negeri 24 Medan with 35 students. This field trial is called the trial I conducted as many as 4 meetings in accordance with the learning implementation plan (RPP) that has been developed. Trial I was conducted to measure the practicality and effectiveness of the learning devices developed based on the guided discovery in the form of Draft II.

1) The Practicality Results of Learning Devices in Trial I

From the results of the practicality analysis of learning devices developed based on guided discoveries, it is found that the learning devices developed have met the practicality criteria, in terms of (1) expert assessment of learning devices developed based on guided discoveries which states that these devices can be used with little revision or without revision; and (2) The results of observations of the feasibility of learning devices in class with a total average in trial I by $86,43 \%$ are in the good category.

2) The Effectiveness Results of Learning Devices in Trial I

From the results of the analysis of trial I data, it is known that the learning devices developed have not met the effectiveness criteria, because there are still indicators that have not yet been met, namely classical student learning completeness and achievement of learning objectives. In the trial I completeness of student learning classically of the results of the post-test mathematical reasoning ability was $62,86 \%$. If referred to the classical students' completeness criteria that are determined, this means that the results of the students' mathematical reasoning posttest results have not met the classical completeness criteria. The level of mastery learning students classically in the trial I can be seen in Figure 1 below:

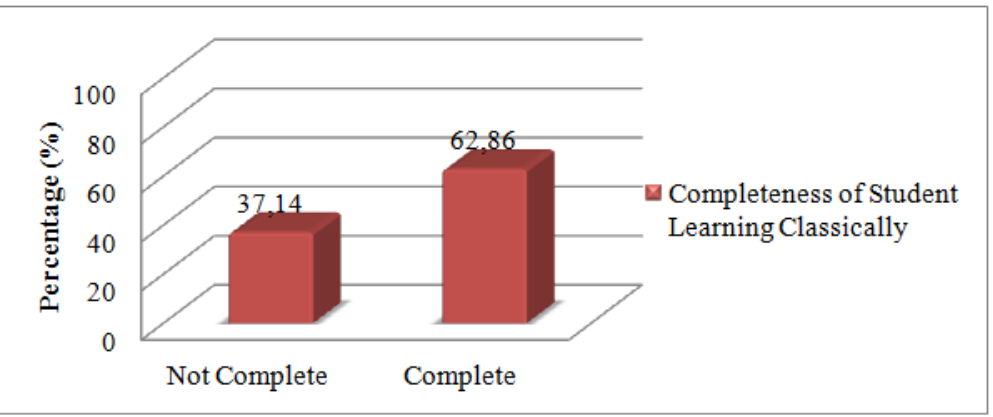

Figure 1. The Percentage of Mastery Learning Students Classically in Trial I

Furthermore, the achievement of learning objectives in the trial I have not yet been reached for each item. Of the five items tested in the trial I, only three items were achieved the learning objective criteria, namely item 1,2 , 
and 3, while the other two items namely item 4 and 5 criteria of learning objectives were not achieved. The level of achievement of learning objectives in the trial I can be seen in Figure 2 below:

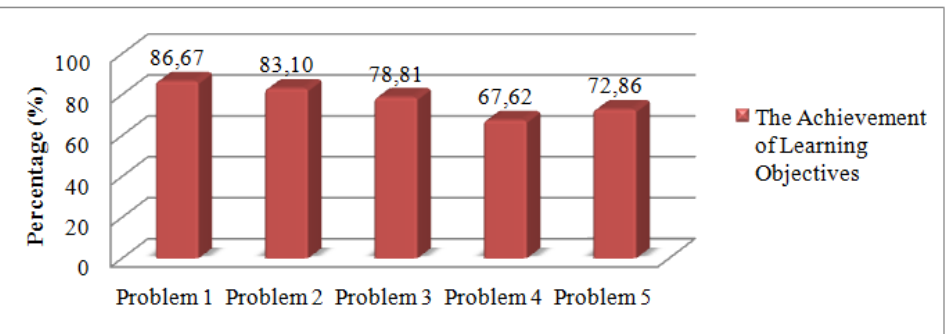

Figure 2. The Percentage of Achievement of Learning Objectives in Trial I

The effectiveness indicators that have been met in the trial $\mathrm{I}$ is the achievement of an ideal time and student response. In the trial I, the time used in the implementation of learning was 10 hours of learning divided into four meetings or $10 \times 40$ minutes. When compared with the usual learning done so far, the overall time spent in implementing learning using the developed device is appropriate or does not exceed a predetermined time limit. In accordance with the criteria for achieving ideal time, which is at least the same learning time as ordinary learning, then the ideal time in the trial I have been reached. Then positive student responses to the components of learning devices developed based on guided discovery. Student responses for each aspect are in a positive category. Furthermore, overall student responses were in the positive category with a total average by $82,34 \%$.

\section{Trial II}

After conducting trial I in Draft II, further improvements were made to produce an effective learning device. The revised results in Draft II resulted in Draft III, which was then tested on students of class VIII-C of SMP Negeri 24 Medan with 35 students. Trial II was conducted to measure Draft III as a guided discovery-based learning device that met all the established effectiveness criteria.

1) The Practicality Results of Learning Devices in Trial II

From the results of the practicality analysis of the developed learning devices based on guided findings, it was found that the learning device developed had fulfilled the practicality criteria. The practicality of the learning device in trial II refers to the results of observations of its implementation in the classroom, with a total average by $91,19 \%$ in the very good category.

2) The Effectiveness Results of Learning Devices in Trial II

From the results of the analysis of the trial II data, it is known that the learning devices developed have met all the effectiveness criteria. In the trial II completeness of student learning classically of the results of the post-test mathematical reasoning ability was $91,43 \%$. If referred to the classical students' completeness criteria for learning, this means that the students' mathematical reasoning post-test results meet the classical completeness criteria. The level of mastery learning students classically in trial II can be seen in Figure 3 below:

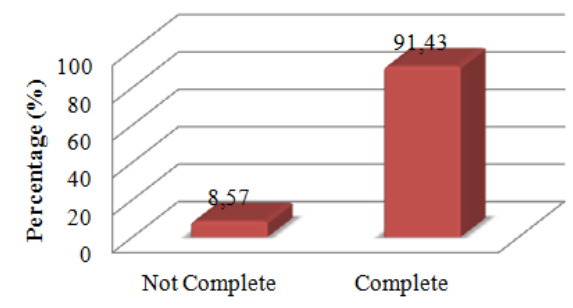

四 Completeness of Student Learning Classically

Figure 3. The Percentage of Mastery Learning Students Classically in Trial II

Furthermore, the criteria for the achievement of learning objectives in trial II have been achieved for each item. The level of achievement of learning objectives in trial II can be seen in Figure 4 below:
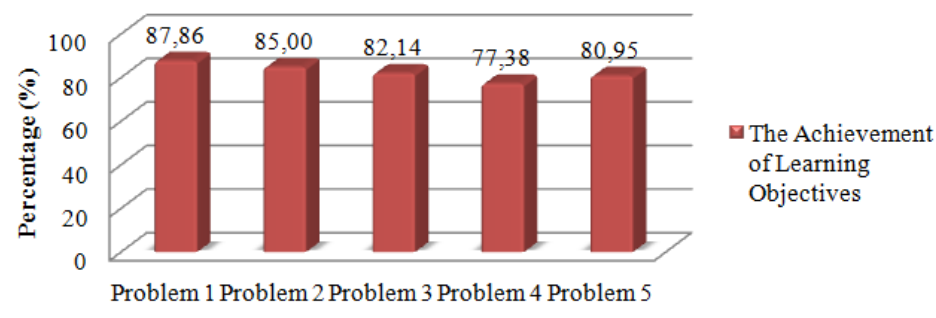

Figure 4. The Percentage of Achievement of Learning Objectives in Trial II 
Meanwhile, achieving the ideal time in trial II has been achieved, namely as many as 10 hours of lessons divided into four meetings or 10 x 40 minutes. When compared with the usual learning done so far, the overall time spent in implementing learning using the developed device is appropriate or does not exceed a predetermined time limit. In accordance with the criteria for achieving ideal time, that is, the minimum learning time is the same as ordinary learning, the achievement of ideal time in trial II has been achieved. Then positive student responses to the components of learning devices developed based on guided discovery. Student responses for each aspect are in a positive category. Furthermore, overall student responses were in the positive category with a total average by $85,66 \%$.

\subsection{Disseminate}

After the learning devices developed are in the form of Final Devices or have met the criteria of validity, practicality, and effectiveness through trials, then the disseminate is carried out by retrying the device at the research site namely SMP Negeri 24 Medan in class VIII-A with 35 students. The disseminate stage is carried out to measure the quality determination of the learning devices developed based on guided discoveries and determine the contribution of the Final Device to improve students' mathematical reasoning abilities and self-esteem.

1) The Practicality Results of Learning Devices at The Disseminate Stage

From the results of the practicality analysis of the developed learning devices based on guided discoveries, it was found that the learning device developed had fulfilled the practicality criteria. The practicality of the learning device at the disseminate stage refers to the results of observations of its implementation in the classroom, with a total average by $94,29 \%$ in the excellent category.

2) The Effectiveness Results of Learning Devices at The Disseminate Stage

From the results of the data analysis of the disseminate stage, it was found that the learning devices developed had met all the effectiveness criteria. At the disseminated stage of completeness of student learning classically of the results of the post-test mathematical reasoning ability was $94,29 \%$. If referred to the classical students' completeness criteria for learning, this means that the students' mathematical reasoning post-test results meet the classical completeness criteria. The level of mastery learning students classically at the disseminate stage can be seen in Figure 5 below:

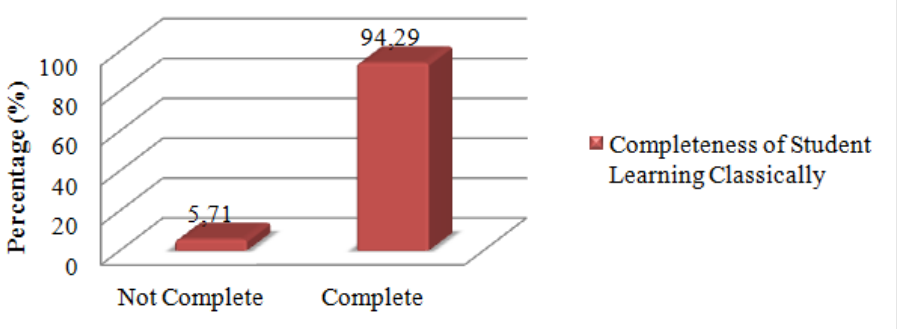

Figure 5. The Percentage of Mastery Learning Students Classically at The Disseminate Stage

Furthermore, the criteria for the achievement of learning objectives at the disseminate stage have been reached for each item. The level of achievement of learning objectives at the disseminate stage can be seen in the following Figure 6:

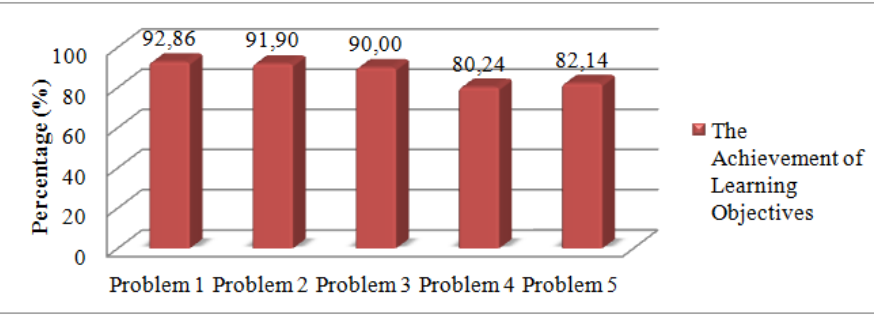

Figure 6. The Percentage of Achievement of Learning Objectives at The Disseminate Stage

Meanwhile, achieving the ideal time at the disseminate stage has been reached, namely 10 learning hours divided into four meetings or $10 \times 40$ minutes. When compared with the usual learning done so far, the overall time spent in implementing learning using the developed device is appropriate or does not exceed a predetermined time limit. In accordance with the criteria for achieving ideal time, which is at least the same learning time as ordinary learning, the ideal time achievement at the disseminate stage has been reached. Then positive student responses to the components of learning devices developed based on guided discovery. Student responses for each aspect are in a positive category. Furthermore, overall student responses were in the positive category with a total average by $87,26 \%$.

3) Improvement of Students' Mathematical Reasoning Abilities at The Disseminate Stage

Based on the results of the disseminate stage, the results of students' mathematical reasoning ability tests were 
obtained. This test is given at the beginning and end of the study which aims to look at students' mathematical reasoning abilities. Data obtained from the results of the student disseminate test were analyzed to determine the increase in students' mathematical reasoning abilities. This increase was seen through N-Gain. The results of NGain calculation tests of mathematical reasoning ability at the disseminate stage consist of N-Gain for indicators of mathematical reasoning and N-Gain for students.

From the results of N-Gain data analysis of mathematical reasoning indicators, it is found that the ability of mathematical reasoning for indicators of presenting allegations has increased by 0,62 with a medium category, indicators, drawing conclusions, compiling evidence, giving reasons or evidence for the truth of solutions experiencing has increased by 0,51 with the medium category, and the indicator checking the validity of an argument has increased by 0,53 with the medium category. This means that the highest improvement in mathematical reasoning indicators after using the learning devices developed at the disseminate stage is the indicator submitting a guess followed by the indicator checking the validity of an argument and finally the indicator drawing conclusions, compiling evidence, giving reasons or proof of the correctness of the solution.

Furthermore, based on the N-Gain for the students it was found that there were no students $(0 \%)$ who experienced an increase in mathematical reasoning abilities with a lower category, 31 students $(88,57 \%)$ had an increase in mathematical reasoning abilities in the medium category, and 4 students $(11,43 \%)$ have increased mathematical reasoning abilities with a high category. So, the average N-Gain of students' mathematical reasoning abilities at the disseminated stage is 0,53 in the medium category.

4) Improvement of Student's Self-Esteem at The Disseminate Stage

Data obtained from the results of self-esteem questionnaires at the disseminate stage were analyzed to determine the increase in students' self-esteem. This increase was seen through N-Gain. The results of the calculation of the $\mathrm{N}-$ Gain self-esteem questionnaire at the disseminate stage consisted of N-Gain for self-esteem aspects and N-Gain for students.

From the results of the analysis of N-Gain data for the aspect of self-esteem, it was found that the self-esteem for the aspect of the sense of security increased by 0,50 in the medium category, the aspect of the sense of identity increased by 0,47 in the medium category, the aspect of sense belonging increased by 0,45 in the medium category, the aspect of the sense of purpose increased by 0,57 in the medium category, and the aspect of the sense of competence increased by 0,51 in the medium category. This means that the highest increase in the aspect of selfesteem after using learning devices developed at the disseminate stage is the aspect of the sense of purpose followed by the aspect of a sense of competence, then the aspect of sense of security, then the aspect of sense of identity, and finally the aspect of sense of belonging.

Furthermore, based on N-Gain for the students it was found that there were 5 students $(14,29 \%)$ who experienced an increase in self-esteem in the low category, 21 students $(60,00 \%)$ experienced an increase in selfesteem in the medium category, and 9 students (35,71\%) experienced an increase in self-esteem with a higher category. So, the average N-Gain self-esteem of students at the disseminated stage is 0.49 in the medium category.

\section{Discussion of Research Results}

\subsection{The Validity of Learning Devices Developed Based on Guided Discovery}

Based on the results of the validation of the learning devices developed, it was found that the components contained in the learning implementation plan (RPP), teacher's book (BG), student book (BS), and student activity sheet (LKS) were declared valid. Likewise, the research instrument which is a mathematical reasoning ability test and self-esteem questionnaire were also declared valid based on expert validation and instrument trials. This shows that the learning devices developed in Draft I have been suitable for use in learning. Validity criteria are obtained based on experts' assessment of learning devices developed based on guided discovery. A valid learning device is obtained because the learning device developed based on guided discovery meets the content and construct validity.

This is in accordance with the statement of Rahmiati, Musdi \& Fauzi (2017: 270) which states that the validity of the learning method must meet the content validity and construct validity. Content validity means the suitability of the product produced with the syllabus of the subject, the suitability of the current curriculum content, and the suitability of the learning devices that will be developed with the student learning experience. The construct validity is the conformity between the product produced and the determined development elements.

\subsection{The Practicality of Learning Devices Developed Based on Guided Discovery}

Based on the results of the practicality analysis of learning devices that are developed based on guided discoveries seen from 2 (two) aspects, namely: 1) expert assessment of learning devices developed based on guided discoveries which state that these devices can be used with little revision or without revisions have been fulfilled and 2) the results of observations of the implementation of learning devices developed based on guided discoveries are in the minimal category Good has also been fulfilled.

This shows that the device is practical in the sense that the learning device developed based on guided discovery is easy to understand and easy to use by teachers and students in the implementation of learning in the 
classroom. In accordance with the statement of Rahmiati, Musdi \& Fauzi (2017: 270) which states that learning devices that are said to be practical are if teachers and students can use these learning devices easily in the learning process.

\subsection{The Effectiveness of Learning Devices Developed Based on Guided Discovery}

Based on the results of the post-test analysis in the trial II and the disseminate stage, it was found that the students 'mathematical reasoning abilities had met the students' classical learning completeness criteria. This is influenced by the application of learning devices developed based on guided discovery. Dewi \& Harahap (2016: 68) states that learning devices are one of the learning devices that can help students in learning. Then Roza, Arnawa \& Yerizon (2018: 236) suggested that discovery learning is a learning model that is in accordance with the characteristics of mathematics learning. In this learning activity learning centered on students, where students are required to learn actively and be given the opportunity to discover their own knowledge and concepts from the material they are learning so that the knowledge obtained by students in learning can be more meaningful and last for a long period of time.

Markaban (2006) (in Burais, Ikhsan \& Duskri, 2016: 80) states that the guided discovery model involves an interaction between students and teachers. Interaction can occur between the teacher and certain students, with several students, or simultaneously with all students in the class. The aim is to influence each other's way of thinking, the teacher provokes students' way of thinking with focused questions so as to enable students to understand and construct certain concepts, build rules and learn to find something to solve problems.

Therefore, the existence of student interaction can also affect the achievement of student learning completeness. The use of learning devices developed based on guided discovery has provided space for students to interact with each other, especially in group discussion activities to understand the material and solve contextual problems that exist in student books and worksheets.

The material and contextual problems have been adjusted to the characteristics of students and arranged with attention to students' minddevices. This has become one of the factors that can affect student learning completeness. By studying the material and solving contextual problems using learning devices that are developed based on guided discovery, student success in learning will be better. This is reinforced by the research results of Trinofita, Susanta \& Hanifah (2019: 1), namely the average value of student learning outcomes taught using the guided discovery learning model is higher than the average value of student learning outcomes taught by expository learning strategies.

Furthermore, based on the results of the analysis of the attainment of the post-test learning objectives students' mathematical reasoning abilities in trial II and the disseminate stage were reached for each item. This shows that the learning objectives that have been device are achieved.

The achievement of learning objectives is influenced by the learning process by using learning devices that are developed based on guided discovery. With the use of these devices, students are actively involved to construct their own knowledge by following the stages of discovery that have been designed in the device. This is supported by Burais, Ikhsan \& Duskri (2016: 79) state that the discovery learning model is one of the learning models that invites students to be actively involved in building their knowledge.

This is also because in the learning devices developed based on guided discoveries, the material students learn is not presented in the final form so students must try to discover their own mathematical concepts. Thus, when given a problem students are able to solve it optimally and have a positive impact on the achievement of learning objectives device. Correspondingly, Burais, Ikhsan \& Duskri (2016: 79-80) stated that "Discovery learning can lead to the formation of the ability to make free discoveries in the future. In this learning, the teacher presents the lesson material not in its final form, such as an instant formula but students have the opportunity to find and find their own core of learning to be achieved ".

Based on the achievement of learning time carried out during trial I, trial II and the disseminate stage obtained the length of learning time using learning devices that are developed based on guided discovery is the same as the normal learning time carried out so far, which is as much as 10 hours of learning divided into four meeting or 10 $\mathrm{x} 40$ minutes. This is in accordance with the criteria for achieving the ideal time, which is at least the same learning time as regular learning. So that the ideal time achievement using learning devices developed based on guided discovery has been achieved. Thus it can be concluded that the ideal time achievement in trial I, trial II and the disseminate stage have been reached.

The achievement of ideal time is inseparable from the teacher's ability to design and manage learning time based on the application of models and learning devices used during the learning process. Especially on guided discovery-based learning that makes learning more meaningful because it links subject matter and contextual issues that are appropriate to the characteristics of students so students are active in participating in learning activities and teachers can use time as effectively as possible. This is in accordance with the opinion of Moreno (2018: 1405-1406), that the knowledge obtained by learning discovery will last longer because it produces knowledge that is truly meaningful, besides the learning outcomes obtained have a better transfer effect than other 
learning outcomes.

As for the results of the analysis of the questionnaire responses of students in the trial I, the trial II and the disseminate stage, it was found that the average percentage of total student responses in each trial was in a positive category. This means that students respond positively to the components of learning devices developed based on guided discovery. In addition, student responses given to each aspect have reached predetermined criteria that are $\geq 80 \%$. This shows that overall students feel helped by the application of the learning device that was developed. Thus it can be concluded that the response of students in trial I, trial II and the disseminate stage was positive.

Positive responses of students are inseparable from the teacher's ability to determine models and design components of learning devices that will be applied in teaching and learning activities. This is in line with the statement of Rahmawati, Mardiyana \& Subanti (2014: 381) that the role of the teacher in determining the model and compiling learning instruments is very necessary. The model applied is guided discovery-based learning. In the application of guided discovery-based learning, students actively participate in the process of discovering their own knowledge and mathematical concepts during learning, especially in group discussion activities using student books and activity sheets that are developed. Bahri, Musmuliadi \& Palennari (2017: 74) argued that student activity sheets (LKS) based on guided discovery can help students in finding material concepts and can be a solution to overcome boredom in the learning process, can foster student curiosity and activeness (finding). Furthermore, with active learning carried out and curiosity will emerge student interest in the learning component that is developed. In addition, learning devices also need to be designed and arranged with attention to grammar and overall content. So that students' intent in the developed device can be clearly understood.

Furthermore, the learning process carried out using learning devices that are developed based on guided discoveries become new things for students. Likewise, the atmosphere of learning in the classroom and the way the teacher teaches is certainly different from the learning normally followed by students. This is consistent with what was stated by Shaffat (2009) (in Rahmawati, Mardiyana \& Subanti, 2014: 381) that the success of learning is also determined by the learning method or method used. Every human individual has differences in many aspects ranging from physical differences, patterns of thinking, and ways to respond or learn new things. So that the learning process that takes place becomes a benchmark for students in responding to learning well.

Positive responses of students are also influenced by the success of teachers in managing learning in the classroom and implementing learning devices that are developed. This success will have an impact on student responses in a positive direction on the components of learning devices developed. This is in accordance with the statement of Sunhaji (2014: 30) that class management is an integral part of the professional abilities that must be possessed by teachers, besides managing class is also one of the basic skills of teaching that aims to create and maintain an optimal learning atmosphere. Furthermore Sunhaji (2014: 30) means that the ability to manage classrooms is closely related to the professional ability of teachers to create favorable conditions, please students and create healthy learning disciplines.

Furthermore, students' interest in ongoing learning also needs attention. In this case, guided discovery-based learning that emphasizes providing the broadest opportunity for students to express ideas, concepts, and ideas into the right choice and appropriate to be applied in learning as an effort to attract students' learning interest. This is in line with Lestari (2013: 117) statement that learning that is fun and is able to give students the freedom to develop personal ideas will increase learning interest. The support of interest in learning is needed to create effective learning.

\subsection{Improvement of Students' Mathematical Reasoning Abilities Who Learn with Learning Devices Developed Based on Guided Discovery}

Based on the results of the test analysis (pretest and post-test) students 'mathematical reasoning ability at the disseminate stage shows that the students' mathematical reasoning ability increases. The increase can be seen from the N-Gain results of mathematical reasoning abilities obtained by students. An increase in mathematical reasoning ability is also seen in each indicator of mathematical reasoning, namely an increase in the indicator of presenting a conjecture, drawing conclusions, compiling evidence, giving reasons or proof of the truth of the solution, and checking the validity of an argument. This shows that the use of learning devices developed based on guided discoveries that have met valid, practical, and effective criteria has an impact on increasing students' mathematical reasoning abilities.

This result is strengthened by research conducted by Sari (2015: 12) that increasing mathematical reasoning ability of students who learn through guided learning is better than students who learn through conventional learning. In line with that in research Burais, Ikhsan \& Duskri (2016: 77) stated that increasing mathematical reasoning ability of students who obtain learning with discovery learning models is better than students who obtain conventional learning in terms of student grouping. This is because through guided discovery learning students are given the opportunity to find answers to the problems given by the teacher in the worksheet through group discussions. In connection with that, Moreno (2018: 1401) in his research showed that the application of learning with the Discovery Learning model can improve the learning process and can improve the ability of mathematical 
understanding. This is revealed by Sari (2015: 13), which is one of the learning models that is expected to facilitate students in improving mathematical reasoning and communication skills, namely guided discovery learning.

Therefore, this also emphasizes that the learning process using guided discovery-based learning devices is one of the factors that can improve students' mathematical reasoning abilities. The guided discovery-based learning process begins with the stimulation stage, namely the provision of mathematical problems by the teacher and students observing the problem in question, then identifies the problem until a hypothesis is obtained, followed by gathering information and processing it to obtain the expected resolution, after which students verify or proof and finally students draw conclusions from the discovery activities they have carried out. This is supported by the statement of Burais, Ikhsan \& Duskri (2016: 81) that based on the stages of learning the discovery learning model can improve students' mathematical reasoning.

In addition, the improvement of students' mathematical reasoning ability is also inseparable from the teacher's ability to design questions that are prepared to train students in reasoning. The question is loaded into the student book and worksheets that are developed in accordance with the reasoning indicators, namely submitting a guess; draw conclusions, compile evidence, provide reasons or evidence for the correctness of the solution; and check the validity of an argument. These questions also facilitate and provide opportunities for students to express their ideas and ideas in practicing mathematical abilities. In connection with that Sari (2015: 13) states that asking the right questions by the teacher will stimulate creativity and students discover new knowledge.

\subsection{Improvement of Student's Self-Esteem Who Learn with Learning Devices Developed Based on Guided Discovery}

Based on the results of the analysis of students' self-esteem questionnaire given before and after using learning devices that were developed in the form of pretest and post-test at the disseminate stage showed that students' selfesteem increased. The increase can be seen from the N-Gain results of self-esteem obtained by students. Increased students' self-esteem is also seen in every aspect of self-esteem, namely an increase in aspects of the sense of security, sense of identity, sense of belonging, sense of purpose, and sense of competence. This shows that the use of learning devices developed based on guided discoveries that have met valid, practical, and effective criteria has an impact on increasing students' self-esteem.

The factors that led to an increase in student self-esteem, namely during the implementation of teacher learning to combine special efforts in order to foster student self-esteem into learning activities at each stage of guided discovery-based learning. Besides that, the teacher also slips written advice in the form of sentences related to self-esteem in the student book and the teacher's book which is arranged in the Self-Esteem Frame, besides that aspect of self-esteem are also contained in all developed learning devices.

Happy \& Widjajanti (2014: 56) states that giving advice is one of the activities that build student morale. As a result, students' self-esteem will increase. Furthermore, Happy \& Widjajanti (2014: 56) also added that in an effort to increase students' self-esteem in the prepared teaching materials, students can strengthen their self-esteem. In class, the teacher plays a very important role in influencing students' self-esteem. The teacher's role is not only to maintain the quality of relationships with students but also to carry out a series of activities that can improve student self-esteem.

\section{Conclusion}

Based on the results of the analysis and discussion in this study, the following conclusions are presented:

1. Learning devices developed based on guided discoveries have met the validity criteria based on the results of expert validation with an average total validity of RPP by 4,51 in the valid category, teacher's book by 4,58 in the valid category, student book by 4,60 is in the valid category, and LKS by 4,49 is in the valid category. While the research instruments validated by experts are test items (pretest and post-test) mathematical reasoning abilities are in the valid category and are quite valid, as well as self-esteem questionnaire statements are in the valid category. Likewise, the results of the validity test of research instrument items in the form of tests (pretest and post-test) mathematical reasoning abilities and self-esteem questionnaires are respectively in the valid and reliable categories.

2. Learning device developed based on guided discoveries have met the practical criteria, in terms of (1) expert assessment of learning devices developed based on guided discovery which state that the device can be used with little or no revision; (2) The results of observations of the feasibility of learning devices in class with a total average of trial I by $86,43 \%$ is in the good category, trial II by $91,19 \%$ is in the very good category, and the disseminate stage by $94,29 \%$ is in the very good category.

3. Learning devices developed based on the guided discovery in the trial I have not met the effectiveness criteria, because there are still indicators that have not yet been met, namely classical student learning completeness and achievement of learning objectives. Whereas in the trial II and the disseminate stage had fulfilled all the effectiveness criteria, in terms of (1) students' mastery learning classically was achieved in the trial II by $91,43 \%$ and the disseminate stage by $94,29 \%$; (2) the achievement of learning objectives have been achieved for each 
item in trial II and the disseminate stage; (3) the learning time used does not exceed or equals the normal learning time; and (4) students' responses have shown responses in the positive category of the components of learning devices developed with an average total in trial II by $85,66 \%$ and the disseminate stage by $87,26 \%$.

4. Improvement of student's mathematical reasoning ability who learn with learning devices developed based on guided discovery can be seen through N-Gain consisting of N-Gain for indicators of mathematical reasoning and N-Gain for students. The highest increase for mathematical reasoning indicators after using the learning devices developed at the dissemination stage is the indicator submitting an estimate by 0,62 followed by the indicator checking the validity of an argument by 0,53 , and finally the indicator draws conclusions, arranges evidence, provides reasons or evidence for the truth solution by 0,51 . With an average N-Gain of students' mathematical reasoning ability at the dissemination stage by 0,53 increased with the medium category.

5. Improvement of student's self-esteem who learn with learning devices developed based on guided discovery can be seen through N-Gain consisting of N-Gain for aspects of self-esteem and N-Gain for students. The highest increase in the aspect of self-esteem after using learning devices developed at the dissemination stage is the aspect of sense of purpose by 0,57 followed by the aspect of sense of competence by 0,51 , then the aspect of sense of security by 0,50 , then the aspect of sense of identity by 0,47 , and finally the aspect of sense of belonging by 0,45 . With an average N-Gain of students' self-esteem at the dissemination stage by 0,49 increased with the medium category.

\section{Acknowledgment}

The author realizes that many parties have been involved and helped in completing this research and journal. Therefore, on this occasion, the author would like to thank profusely to relevant parties, namely the leaders of the UNIMED Postgraduate Program and their staff, thesis supervisors, and school principals, teachers and students of SMP Negeri 24 Medan.

\section{References}

Achera, L.J., Belecina, R.R., \& Garvida, M.D. (2015). The effect of group guided discovery approach on the performance of students in geometry. International Journal of Multidisciplinary Research and Modern Education (IJMRME), 1(2), 331-342.

Adibah, F. (2013). Pengembangan perangkat pembelajaran matematika dengan pendekatan inkuiri di kelas VIII MTs Negeri 2 Surabaya. Jurnal Widyaloka Ikip Widyadarma Surabaya, 1(1), 1-19.

Arikunto, S. 2013. Prosedur penelitian suatu pendekatan praktik. Jakarta: Rineka Cipta.

Arnita. 2013. Pengantar statistika. Bandung: Citapustaka Medan Perintis.

Bahri, A., Musmuliadi, S., \& Palennari, M. (2017). Pembelajaran efektif: meningkatkan hasil belajar peserta didik melalui penggunaan lembar kerja berbasis penemuan terbimbing. Jurnal Penelitian Pendidikan Insani, 20(2), 73-79.

Barus, E.M. (2018). Pengaruh penerapan pendekatan kontekstual terhadap kemampuan berpikir kritis matematika siswa SMP ST. Thomas 1 Medan. Cartesius: Jurnal Pendidikan Matematika, 1(1), 10-24.

Burais, L., Ikhsan, M., \& Duskri, M. (2016). Peningkatan kemampuan penalaran matematis siswa melalui model discovery learning. Jurnal Didaktik Matematika, 3(1), 77-86.

Dewi, I., \& Harahap, M.S. (2016). The development of geometri teaching materials based on constructivism to improve the students' mathematic reasoning ability through cooperative learing jigsaw at the class VIII of SMP Negeri 3 Padangsidimpuan. Journal of Education and Practice, 7(29), 68-82.

Happy, N., \& Widjajanti, D.B. (2014). Keefektifan pbl ditinjau dari kemampuan berpikir kritis dan kreatif matematis, serta self-esteem siswa SMP. Jurnal Ridevice Pendidikan Matematika, 1(1), 48-57.

Julia, Y. (2017). Pengaruh self esteem terhadap aktivitas belajar kelas XI IPS di SMA Santo Fransiskus Asisi Pontianak. Jurnal Pendidikan dan Pembelajaran Khatulistiwa, 6(10), 1-10.

Lestari, I. (2013). Pengaruh waktu belajar dan minat belajar terhadap hasil belajar matematika. Jurnal Formatif, $3(2), 115-125$.

Moreno, L. (2018). Penerapan model discovery learning untuk meningkatkan kemampuan pemahaman matematis siswa kelas VII SMPN 25 Pekanbaru. Jurnal Pendidikan Tambusai. 2(6), 1401-1428.

Mujahidah, L. \& Suhendar, U. (2018). Penerapan pendekatan contextual teaching and learning (ctl) untuk meningkatkan disposisi matematis siswa kelas VIIIA SMP N 2 Pulung. Edumatica, 8(2), 55-67.

Prihadi, K., \& Chua, M. (2012). Students' self-esteem at school: the risk, the challenge, and the cure. Journal of Education and Learning, 6(1),1-14.

Purnamasari, K. \& Lestari, H.P. (2017). Pengembangan perangkat pembelajaran untuk SMP kelas VII materi segitiga dan segi empat melalui pendekatan kontekstual dan model pembelajaran probing prompting. Jurnal Pendidikan Matematika, 6(1), 18-30.

Rafiqoh, S., Syahputra, E., \& Surya, E. (2015). Peningkatan kemampuan penalaran dan koneksi matematis siswa SMA Negeri 1 Air Joman melalui pembelajaran berbasis masalah. Jurnal Paradikma, 8(2), 109-120. 
Rahmawati, Y., Mardiyana \& Subanti, S. (2014). Pengembangan perangkat pembelajaran berbasis penemuan terbimbing (guided discovery) dengan pendekatan somatic, auditory, visual, intellectual (SAVI) pada materi pokok peluang kelas IX SMP tahun pelajaran 2013/2014. Jurnal Elektronik Pembelajaran Matematika, 2(4), $379-388$

Rahmiati, Musdi, E., \& Fauzi, A. (2017). Pengembangan perangkat pembelajaran matematika berbasis discovery learning untuk meningkatkan kemampuan pemecahan masalah siswa kelas VIII SMP. Jurnal "Mosharafa”, 6(2), 267-272.

Roza, N., Arnawa, I.M., \& Yerizon. (2018). Practicality of mathematics learning tools based on discovery learning for topic sequence and series. International Journal of Scientific \& Technology Research, 7(5), 236-241.

Safitri, Y., \& Arnawa, I.M. (2019). Mathematics learning device development based on constructivism approach to improve mathematical reasoning skill of class X students in vocational high school (SMK). International Journal of Scientific \& Technology Research, 8(5), 131-135.

Sari, R.N. (2015). Peningkatan kemampuan penalaran matematis siswa SMP melalui pembelajaran penemuan terbimbing. Pythagoras, 4(2), 12-18.

Sifanu, M. (2018). The impact of guided discovery learning on the performance of grade 11 learners in identification of ions. Journal of Education and Practice, 9(20), 77-81.

Simanungkalit, R.H. (2016). Pengembangan perangkat pembelajaran untuk meningkatkan kemampuan pemecahan masalah matematis siswa SMP Negeri 12 Pematangsiantar. MUST: Journal of Mathematics Education, Science and Technology, 1(1), 39-56.

Siregar, A.F., \& Jaya, I. (2016). Hasil belajar matematika dengan menggunakan model pembelajaran kooperatif tipe teams games tournament (TGT) dan pembelajaran tipe teams assisted individualization (TAI) dengan pemanfaatan LKS dan alat peraga pada materi geometri bangun ruang di kelas X SMA Sinar Husni Medan tahun pelajaran 2015/2016. AXIOM, 5(2), 133-151.

Sunhaji. (2014). Konsep manajemen kelas dan implikasinya dalam pembelajaran. Jurnal Kependidikan, 2(2), 3046.

Sunismi. (2015). Developing guided discovery learning materials using mathematics mobile learning application as an alternative media for the students calculus II. Cakrawala Pendidikan, 34(3), 334-346.

Switaj, P., Grygiel, P., Chrostek, A., Nowak, I., Wciorka, J., \& Anczewska, M. (2017). The relationship between internalized stigma and quality of life. among people with mental illness: are self-esteem and sense of coherence sequential mediators?. Quality of Life Research, 26, 2471-2478.

Tanjung, H.S. \& Nababan, S.A. (2018). Pengembangan perangkat pembelajaran matematika berorientasi model pembelajaran berbasis masalah (pbm) untuk meningkatkan kemampuan berpikir kritis siswa SMA Se-Kuala Nagan Raya Aceh. Genta Mulia, 9(2), 56-70.

Trinofita, B., Susanta, A., \& Hanifah. (2019). Pengaruh model pembelajaran penemuan terbimbing terhadap hasil belajar siswa SMP Negeri 11 Kota Bengkulu. Jurnal Penelitian Pembelajaran Matematika Sekolah (JP2MS), $3(1), 1-5$. 